\title{
Characteristics of reactive oxygen metabolites in serum of early teenagers in Japan
}

\author{
Terumi Kogawa $\cdot$ Miya Nishimura $\cdot$ \\ Shizuka Kurauchi · Ikuo Kashiwakura
}

Received: 27 September 2011/ Accepted: 12 December 2011/Published online: 30 December 2011

(C) The Japanese Society for Hygiene 2011

\begin{abstract}
Objectives The relationship between the incidence of cardiovascular disease and the state of oxidative stress in blood has been studied to some extent. Several lines of evidence underscore the importance of primary prevention of cardiovascular disease beginning in childhood. However, little is known about the current state of oxidative stress in childhood. This study was carried out to determine the current state of the level of reactive oxygen metabolites (ROM) in serum of early teenagers.

Methods This study enrolled 595 healthy junior high school students from the town of Nanbu located in northern Japan. Oxidative stress was evaluated by measuring the serum level of ROM, and antioxidant capacity was evaluated by measuring the serum level of biological antioxidant potential (BAP). Results Although the ROM level in female students $[308.6 \pm 63.1$ Carratelli units (U.CARR)] was slightly higher than that in males (299.9 \pm 55.2 U.CARR), the difference was not statistically significant. The BAP level in males was significantly higher than that in females. The levels of ROM and BAP detected in males in the first grade were higher than those in the other grades. In females, only first-graders' BAP was higher than that in other grades. Conclusions The current study found that the ROM level in males was negatively correlated with grade. These
\end{abstract}

T. Kogawa $(\varangle) \cdot$ M. Nishimura $\cdot$ S. Kurauchi

Department of Health Promotion, Hirosaki University Graduate

School of Health Sciences, 66-1 Hon-cho, Hirosaki,

Aomori 036-8564, Japan

e-mail: t_kogawa@cc.hirosaki-u.ac.jp

I. Kashiwakura

Department of Radiological Life Sciences, Hirosaki University

Graduate School of Health Sciences, 66-1 Hon-cho,

Hirosaki 036-8564, Japan results suggest the presence of factor(s) that increase oxidative stress in Japanese puberty.

Keywords Oxidative stress - Gender - Healthy puberty · Primary prevention

\section{Introduction}

In Japan, lifestyle-related disease is a cause of about $60 \%$ of deaths and accounts for about 30\% of national health care costs; thus, such disease represents a very important national administration and medical economic issue. Among lifestyle-related diseases, cardiovascular disease proceeds slowly from childhood [1], and high rates of occurrence and mortality in adults have been reported $[2,3]$. In countries of Europe and America, mortality due to cardiovascular disease is decreasing, while limited improvement has been observed in Japan [4-6]. Westernization of eating habits related to changes in lifestyle have increased the number of people at risk for diabetes, hypertension, and hyperlipidemia, necessitating formulation of countermeasures against the evolution of poor lifestyle and eating habits in developing children.

A recent report documented the relationship between the incidence of cardiovascular disease and the state of oxidative stress in blood $[1,2,7,8]$. It is believed that various reactive oxygen species (ROS) are increased due to risk factors such as diabetes, hypertension, and hyperlipidemia. Since oxidative stress is promoted by these risk factors, the resulting incidence of cardiovascular disease may be increased. Thus, in order to devise countermeasures against these risk factors that will be effective during childhood, it is necessary to understand the state of oxidative stress in the blood of individual children before risk factors develop. 
However, the many previous studies regarding oxidative stress have mainly focused on case studies $[9,10]$, animal experiments [11], and adults [3, 7, 8, 12]. Although studies on healthy pediatric population have shown the effects of environmental factors such as air pollution [13] and passive smoking [14], these studies do not provide complete information, because they included healthy pediatric subjects with inadequate breakdown by age. In childhood, the measures used should depend on developmental stage. Therefore, detailed understanding of the oxidative stress state by age group is necessary.

To obtain useful insights for developing these protective measures, blood redox levels were measured using commercially available kits, reactive oxygen metabolites (ROMs) test (i.e., the d-ROMs test), and biological antioxidant potential (BAP) test, which were previously found to be useful indicators of oxidative stress $[15,16]$.

\section{Methods}

\section{Study design}

The study was performed in the town of Nanbu, located in the northern part of Honshu, the main island of Japan. As of
November 30, 2011, the total area, population, and number of households in Nanbu were $153.15 \mathrm{~km}^{2}, 20647$ people, and 7485 , respectively [17]. Extending linearly along the Mabechi River that flows through the center of the city, this area of plains possesses rich soil, and Nakui Mountain, at an altitude of $615 \mathrm{~m}$ and located southwest of the town, endows the region with a rich natural countryside. Though the main industry in this town is agriculture, including rice culture and fruit growing, the population includes many salaried office employees who work at companies established in a nearby urban area. The average annual temperature is $9.5^{\circ} \mathrm{C}$, and the lowest and highest temperatures range from $-6^{\circ} \mathrm{C}$ to $7^{\circ} \mathrm{C}$ in February and from $20^{\circ} \mathrm{C}$ to $25^{\circ} \mathrm{C}$ in August. There is little snow in winter, but the cold is quite severe. The annual number of births has gradually decreased every year, and is now about 150 [18].

Since 2006, Nanbu has performed medical health examinations with peripheral blood collection, as part of the town's "preventive medical health examination against lifestyle-related disease in young people" project. The present study participated in this project from 2008, and this report summarizes the data obtained in 2010. The present study surveyed 615 students (from 12 to 15 years of age) in 4 junior high schools located in Nanbu during the period from April to May 2010. Before collecting blood,

Table 1 Characteristics of study participants

\begin{tabular}{llll}
\hline Measurement item & $\begin{array}{l}\text { All }(n=595) \\
\text { Mean }(\mathrm{SD})\end{array}$ & $\begin{array}{l}\text { Male }(n=312) \\
\text { Mean }(\mathrm{SD})\end{array}$ & $\begin{array}{l}\text { Female }(n=283) \\
\text { Mean }(\mathrm{SD})\end{array}$ \\
\hline Height $(\mathrm{cm})$ & $157.1(8.2)$ & $159.4(9.1)$ & $154.6(6.2)$ \\
Weight $(\mathrm{kg})$ & $49.9(10.3)$ & $51.0(10.8)$ & $48.7(9.6)$ \\
BMI $\left(\mathrm{kg} / \mathrm{m}^{2}\right)$ & $20.1(3.2)$ & $19.9(3.1)$ & $20.3(3.4)$ \\
Systolic BP $(\mathrm{mmHg})$ & $110.5(8.4)$ & $111(8.5)$ & $109(8.1)$ \\
Diastolic BP $(\mathrm{mmHg})$ & $63.0(8.7)$ & $62(9.1)$ & $64(8.2)$ \\
AST $(\mathrm{U} / \mathrm{L})$ & $21.1(5.2)$ & $23.1(5.7)$ & $18.9(3.4)$ \\
ALT $(\mathrm{mg} / \mathrm{dL})$ & $14.9(9.3)$ & $17.0(11.7)$ & $12.5(4.7)$ \\
Total cholesterol $(\mathrm{mg} / \mathrm{dL})$ & $162.1(25.6)$ & $157.6(26.4)$ & $167.0(23.7)$ \\
Triglycerides $(\mathrm{mg} / \mathrm{dL})$ & $73.9(42.4)$ & $70.5(44.4)$ & $77.7(39.8)$ \\
HDL-cholesterol $(\mathrm{mg} / \mathrm{dL})$ & $59.4(14.4)$ & $58.7(14.8)$ & $60.0(13.9)$ \\
LDL-cholesterol $(\mathrm{mg} / \mathrm{dL})$ & $83.6(21.2)$ & $80.2(21.8)$ & $87.3(19.9)$ \\
WBC $\left(\times 10^{3} / \mu \mathrm{L}\right)$ & $61.3(13.9)$ & $59.3(12.9)$ & $63.5(14.6)$ \\
RBC $\left(\times 10^{4} / \mu \mathrm{L}\right)$ & $486.1(38.4)$ & $503.6(35.1)$ & $466.7(32.1)$ \\
Hemoglobin $(\mathrm{g} / \mathrm{dL})$ & $13.5(1.3)$ & $14.0(1.2)$ & $13.0(1.2)$ \\
Hematocrit $(\%)$ & $42.1(3.5)$ & $43.2(3.4)$ & $40.9(3.1)$ \\
Platelets $\left(\times 10^{4} / \mu \mathrm{L}\right)$ & $26.9(5.4)$ & $26.9(5.2)$ & $26.9(5.6)$ \\
d-ROMs $(\mathrm{U} . \mathrm{CARR})$ & $304.0(59.2)$ & $299.9(55.2)$ & $308.6(63.1)$ \\
BAP $(\mu \mathrm{mol} / \mathrm{L})$ & $2713.9(119.8)$ & $2745.5(108.1)$ & $2679.0(122.6)$ \\
\hline A $t$ test $w a s ~$ & & $* * *$ \\
$* * *$
\end{tabular}

A $t$ test was used to compare parameters between genders

$B M I$ body mass index, $B P$ blood pressure, $A S T$ aspartate aminotransferase, $A L T$ alanine transaminase, $H D L$ high-density lipoprotein, $L D L$ lowdensity lipoprotein, $W B C$ white blood cells, $R B C$ red blood cells, $d$-ROMs reactive oxygen metabolite (ROM) test, $B A P$ biological antioxidant potential, U.CARR Carratelli units, $S D$ standard deviation

$* P<0.05, * * P<0.01, * * * P<0.001$ 
we carefully outlined the purposes of the study and provided oral and written declarations to the students and their parents that there would be no disadvantage resulting from rejection to participate in the study. After informed consent was obtained, peripheral blood was collected from 595 students, a participation rate of $96.7 \%$. There were 109 males in the first grade (from 12 years 1 month to 13 years 0 months of age), 111 in the second grade (from 13 years 1 month to 14 years 0 months of age), and 92 in the third grade (from 14 years 1 month to 15 years 0 months of age); there were 97, 93, and 93 females in each grade, respectively. This study was approved by the Committee of Medical Ethics of Hirosaki University Graduate School of Medicine (Hirosaki, Japan).

\section{Measurement of ROM and BAP}

ROMs were measured using the d-ROMs test (Diacron International, Grosseto, Italy). The d-ROMs test, which has been shown to be a new plasma biomarker to predict a first atherothrombotic event [15], is a photometric test used to measure the concentration of hydroperoxides ( $\mathrm{ROOH})$ in biological samples using the principle of Fenton's reaction. In an acidified medium, bivalent and trivalent forms of iron from the protein component of blood are ionized and used as catalysts for breakdown of hydroperoxide groups in blood into alkoxyl and peroxy radicals to obtain free radicals. These are transferred into a cuvette containing colorless chromogen ( $N, N$-diethyl- $P$-phenylenediamine), which is then oxidized by free radicals into a radical cation with magenta color. The density of the magenta color reflects the concentration of hydroperoxides in the blood, which is proportional to the quantity of ROMs [16]. In healthy subjects, ROM has a normal range of values between 250 and 300 Carratelli units (U.CARR) [19].

The level of BAP was measured by the BAP test (Diacron International), which determines the BAP of blood plasma by measuring its ferric reducing ability, i.e., the transformation of iron from ferric to ferrous form. BAP was also simultaneously measured. When the salt of a trivalent iron $\left(\mathrm{FeCl}_{3}\right)$ is dissolved in a colorless solution containing a chelation acid derivative, the solution turns red because of the action of the $\mathrm{Fe}^{3+}$ ions; however, the solution is decolorized again by the addition of blood plasma because of the reduction of $\mathrm{Fe}^{2+}$ ions by the antioxidant action. In theory, the antioxidant potential of blood plasma can be evaluated by measuring the degree of decolorization using a photometer. The normal value for the BAP test in healthy subjects is over $2200 \mu \mathrm{mol} / \mathrm{L}$. A value lower than $2200 \mu \mathrm{mol} / \mathrm{L}$ indicates reduced BAP and

Table 2 Summary and comparison of characteristics of analyzed items detected in serum

\begin{tabular}{llll}
\hline Measurement item & $\begin{array}{l}\text { 1st grade }(n=206) \\
\text { Mean }(\mathrm{SD})\end{array}$ & $\begin{array}{l}\text { 2nd grade }(n=204) \\
\text { Mean }(\mathrm{SD})\end{array}$ & $\begin{array}{l}\text { 3rd grade }(n=185) \\
\text { Mean }(\mathrm{SD})\end{array}$ \\
\hline Height $(\mathrm{cm})$ & $151.8(7.1)$ & $158.5(7.5)$ & $161.5(6.8)$ \\
Weight $(\mathrm{kg})$ & $46.0(10.1)$ & $49.6(8.8)$ & $54.5(10.2)$ \\
BMI $\left(\mathrm{kg} / \mathrm{m}^{2}\right)$ & $19.8(3.5)$ & $19.7(2.6)$ & $20.9(3.5)$ \\
Systolic BP $(\mathrm{mmHg})$ & $109.8(7.7)$ & $110.9(9.3)$ & $110.8(8.0)$ \\
Diastolic BP $(\mathrm{mmHg})$ & $62.6(8.6)$ & $62.7(8.9)$ & $63.7(8.5)$ \\
AST $(\mathrm{U} / \mathrm{L})$ & $21.8(5.4)$ & $21.0(5.0)$ & $20.4(5.1)$ \\
ALT $(\mathrm{mg} / \mathrm{dL})$ & $15.9(13.4)$ & $13.8(5.6)$ & $15.0(6.7)$ \\
Total cholesterol $(\mathrm{mg} / \mathrm{dL})$ & $164.7(25.8)$ & $160.9(24.5)$ & $160.5(26.4)$ \\
Triglycerides $(\mathrm{mg} / \mathrm{dL})$ & $80.2(43.3)$ & $64.2(32.3)$ & $77.7(48.9)$ \\
HDL-cholesterol $(\mathrm{mg} / \mathrm{dL})$ & $59.6(13.9)$ & $60.4(13.9)$ & $57.9(15.4)$ \\
LDL-cholesterol $(\mathrm{mg} / \mathrm{dL})$ & $85.7(22.4)$ & $82.1(19.6)$ & $83.0(21.5)$ \\
WBC $\left(\times 10^{3} / \mu \mathrm{L}\right)$ & $62.5(13.5)$ & $58.6(11.9)$ & $62.9(15.8)$ \\
RBC $\left(\times 10^{4} / \mu \mathrm{L}\right)$ & $486.4(36.4)$ & $485.8(37.5)$ & $485.9(41.6)$ \\
Hemoglobin $(\mathrm{g} / \mathrm{dL})$ & $13.5(1.1)$ & $13.4(1.4)$ & $13.6(1.5)$ \\
Hematocrit $(\%)$ & $41.7(2.8)$ & $42.0(3.7)$ & $42.5(3.8)$ \\
Platelets $\left(\times 10^{4} / \mu \mathrm{L}\right)$ & $27.4(5.0)$ & $26.8(5.4)$ & $26.5(5.8)$ \\
d-ROMs $(\mathrm{U} . \mathrm{CARR})$ & $311.1(59.4)$ & $306.3(58.6)$ & $293.8(58.6)$ \\
BAP $(\mu \mathrm{mol} / \mathrm{L})$ & $2768.4(113.4)$ & $2690.1(118.4)$ & $2679.4(106.9)$ \\
\hline Analys & & $\mathrm{bc}$ & $\mathrm{b}$
\end{tabular}

Analysis of variance (ANOVA) was used to compare parameters among the 3 grades

$B M I$ body mass index, $B P$ blood pressure, $A S T$ aspartate aminotransferase, $A L T$ alanine transaminase, $H D L$ high-density lipoprotein, $L D L$ lowdensity lipoprotein, $W B C$ white blood cells, $R B C$ red blood cells, $d$-ROMs reactive oxygen metabolite (ROM) test, $B A P$ biological antioxidant potential, U.CARR Carratelli units, $S D$ standard deviation

Tukey test $P<0.05,{ }^{\mathrm{a}} 1$ st grade $\times 2$ nd grade, ${ }^{\mathrm{b}} 1$ st grade $\times 3 \mathrm{rd}$ grade, ${ }^{\mathrm{c}} 2$ nd grade $\times 3$ rd grade 
requires clinical attention [16]. Each measurement was performed by an automatic biochemical analyzer (TBA120FR; Toshiba Medical Systems Corporation, Japan).

In addition to the above measurements, a standard blood test was performed, including counts of white blood cells (WBC), red blood cells (RBC), and platelets; hemoglobin value; and hematocrit (XT-2000i; Sysmex, Japan). The levels of aspartate aminotransferase (AST), alkaline phosphatase (ALT), total cholesterol, triglyceride, high-density lipoprotein (HDL) cholesterol, and low-density lipoprotein (LDL) cholesterol were also analyzed (TBA-120FR; Toshiba Medical Systems Corporation, Japan).

\section{Statistical analysis}

The significance of the difference in mean values between 2 groups was analyzed using Student's $t$ test. Data from 3 groups were analyzed using one-way analysis of variance (ANOVA), with post hoc comparison using the TukeyKramer multiple test. Statistical analysis was performed using SPSS software, version 12.0 (SPSS Japan, Tokyo, Japan) for Windows. A value of $P<0.05$ was considered to be statistically significant.

\section{Results}

Subjects' physical characteristics, biochemical values, and degree of oxidation and reduction

The total number of students (595) included 312 males and 283 females (Table 1). The mean height and weight were higher in males than in females. In addition, the biochemical values of AST, ALT, RBC, hemoglobin, and hematocrit were higher in males than in females, but total cholesterol LDL, and WBC counts were higher in females than in males. The level of BAP and the degree of reduction were higher in males than in females, although no difference was observed in ROM levels between the genders. ROM and BAP levels showed a weak and insignificant correlation.

Comparison of the characteristics of each grade

Each data item was compared among the school grades (Table 2). The mean values of height and weight significantly increased with grade. AST, triglyceride, and WBC levels showed significant differences among the grades.

Table 3 Summary and comparison of characteristics of analyzed items detected in males' serum

\begin{tabular}{llll}
\hline Measurement item & $\begin{array}{l}\text { 1st grade }(n=109) \\
\text { Mean }(\mathrm{SD})\end{array}$ & $\begin{array}{l}\text { 2nd grade }(n=111) \\
\text { Mean (SD) }\end{array}$ & $\begin{array}{l}\text { 3rd grade }(n=92) \\
\text { Mean }(\mathrm{SD})\end{array}$ \\
\hline Height $(\mathrm{cm})$ & $152.0(7.6)$ & $161.4(7.6)$ & $165.6(5.8)$ \\
Weight $(\mathrm{kg})$ & $46.4(10.0)$ & $51.4(9.7)$ & $56.1(10.7)$ \\
BMI $\left(\mathrm{kg} / \mathrm{m}^{2}\right)$ & $19.9(3.4)$ & $19.6(2.7)$ & $20.4(3.3)$ \\
Systolic BP $(\mathrm{mmHg})$ & $109(7.6)$ & $112(9.8)$ & $113(7.4)$ \\
Diastolic BP $(\mathrm{mmHg})$ & $61(8.5)$ & $62(9.3)$ & $64(9.3)$ \\
AST $(\mathrm{U} / \mathrm{L})$ & $23.6(5.9)$ & $23.0(5.4)$ & $22.6(5.7)$ \\
ALT $(\mathrm{mg} / \mathrm{dL})$ & $18.5(17.1)$ & $15.5(6.4)$ & $17.2(8.0)$ \\
Total cholesterol $(\mathrm{mg} / \mathrm{dL})$ & $162.0(28.7)$ & $157.6(25.1)$ & $152.4(24.4)$ \\
Triglycerides $(\mathrm{mg} / \mathrm{dL})$ & $77.4(47.9)$ & $60.0(31.0)$ & $75.0(51.5)$ \\
HDL-cholesterol $(\mathrm{mg} / \mathrm{dL})$ & $60.0(14.6)$ & $60.6(15.3)$ & $54.9(13.8)$ \\
LDL-cholesterol $(\mathrm{mg} / \mathrm{dL})$ & $82.8(24.0)$ & $78.8(18.6)$ & $78.9(22.5)$ \\
WBC $\left(\times 10^{3} / \mu \mathrm{L}\right)$ & $61.8(14.0)$ & $55.7(10.0)$ & $60.6(13.9)$ \\
RBC $\left(\times 10^{4} / \mu \mathrm{L}\right)$ & $497.3(36.6)$ & $502.7(32.3)$ & $512.2(35.3)$ \\
Hemoglobin $(\mathrm{g} / \mathrm{dL})$ & $13.6(1.2)$ & $13.9(1.1)$ & $14.4(1.4)$ \\
Hematocrit $(\%)$ & $41.9(3.1)$ & $43.2(3.0)$ & $44.5(3.6)$ \\
Platelets $\left(\times 10^{4} / \mu \mathrm{L}\right)$ & $28.0(5.1)$ & $26.2(4.8)$ & $\mathrm{b}$ \\
d-ROMs $(\mathrm{U} . \mathrm{CARR})$ & $316.0(57.7)$ & $299.9(46.3)$ & $\mathrm{ac}$ \\
BAP $(\mu \mathrm{mol} / \mathrm{L})$ & $2795.6(111.6)$ & $2731.6(89.8)$ & $\mathrm{bc}$ \\
\hline Antysis & & $\mathrm{bc}(5.7)$ & $\mathrm{bc}$
\end{tabular}

Analysis of variance (ANOVA) was used to compare parameters among the 3 grades

$B M I$ body mass index, $B P$ blood pressure, $A S T$ aspartate aminotransferase, $A L T$ alanine transaminase, $H D L$ high-density lipoprotein, $L D L$ lowdensity lipoprotein, $W B C$ white blood cells, $R B C$ red blood cells, $d$-ROMs reactive oxygen metabolite (ROM) test, $B A P$ biological antioxidant potential, U.CARR Carratelli units, $S D$ standard deviation

Tukey test $P<0.05,{ }^{\mathrm{a}} 1$ st grade $\times 2$ nd grade, ${ }^{\mathrm{b}} 1$ st grade $\times 3$ rd grade, ${ }^{\mathrm{c}} 2$ nd grade $\times 3$ rd grade 
Table 4 Summary and comparison of characteristics of analyzed items detected in females' serum

\begin{tabular}{llll}
\hline Measurement item & $\begin{array}{l}\text { 1st grade }(n=97) \\
\text { Mean }(\mathrm{SD})\end{array}$ & $\begin{array}{l}\text { 2nd grade }(n=93) \\
\text { Mean }(\mathrm{SD})\end{array}$ & $\begin{array}{l}\text { 3rd grade }(n=93) \\
\text { Mean }(\mathrm{SD})\end{array}$ \\
\hline Height $(\mathrm{cm})$ & $151.5(6.4)$ & $155.1(5.6)$ & $157.4(5.0)$ \\
Weight $(\mathrm{kg})$ & $45.6(10.3)$ & $47.5(7.0)$ & $53.0(9.5)$ \\
BMI $\left(\mathrm{kg} / \mathrm{m}^{2}\right)$ & $19.7(3.6)$ & $19.7(2.5)$ & $21.4(3.6)$ \\
Systolic BP $(\mathrm{mmHg})$ & $110(7.8)$ & $109(8.4)$ & $109(8.2)$ \\
Diastolic BP $(\mathrm{mmHg})$ & $64(8.6)$ & $63(8.3)$ & $64(7.7)$ \\
AST $(\mathrm{U} / \mathrm{L})$ & $19.8(3.8)$ & $18.5(3.2)$ & $18.3(3.1)$ \\
ALT $(\mathrm{mg} / \mathrm{dL})$ & $13.0(5.9)$ & $11.7(3.7)$ & $12.8(4.0)$ \\
Total cholesterol $(\mathrm{mg} / \mathrm{dL})$ & $167.8(21.9)$ & $164.7(23.3)$ & $168.5(25.9)$ \\
Triglycerides $(\mathrm{mg} / \mathrm{dL})$ & $83.4(37.5)$ & $69.2(33.4)$ & $80.3(46.4)$ \\
HDL-cholesterol $(\mathrm{mg} / \mathrm{dL})$ & $59.1(13.2)$ & $60.2(12.0)$ & $60.9(16.4)$ \\
LDL-cholesterol $(\mathrm{mg} / \mathrm{dL})$ & $88.9(20.0)$ & $86.0(20.1)$ & $87.0(19.7)$ \\
WBC $\left(\times 10^{3} / \mu \mathrm{L}\right)$ & $63.4(13.0)$ & $62.1(13.2)$ & $65.1(17.2)$ \\
RBC $\left(\times 10^{4} / \mu \mathrm{L}\right)$ & $474.1(32.3)$ & $465.7(33.3)$ & $459.9(29.1)$ \\
Hemoglobin $(\mathrm{g} / \mathrm{dL})$ & $13.3(0.9)$ & $12.8(1.5)$ & $12.8(1.1)$ \\
Hematocrit $(\%)$ & $41.5(2.5)$ & $40.6(3.8)$ & $40.5(2.8)$ \\
Platelets $\left(\times 10^{4} / \mu \mathrm{L}\right)$ & $26.7(4.8)$ & $27.5(6.0)$ & $26.6(5.9)$ \\
d-ROMs $(\mathrm{U} . \mathrm{CARR})$ & $305.5(61.2)$ & $313.9(70.1)$ & $306.5(57.9)$ \\
BAP $(\mu \mathrm{mol} / \mathrm{L})$ & $2737.8(108.0)$ & $2640.5(129.3)$ & $2656.1(107.2)$ \\
\hline Analysis $0 \mathrm{vab}$ & $\mathrm{b}$
\end{tabular}

Analysis of variance (ANOVA) was used to compare parameters among the 3 grades

$B M I$ body mass index, $B P$ blood pressure, $A S T$ aspartate aminotransferase, $A L T$ alanine transaminase, $H D L$ high-density lipoprotein, $L D L$ lowdensity lipoprotein, $W B C$ white blood cells, $R B C$ red blood cells, $d$-ROMs reactive oxygen metabolite (ROM) test, $B A P$ biological antioxidant potential, U.CARR Carratelli units, $S D$ standard deviation

Tukey test $P<0.05,{ }^{\mathrm{a}} 1$ st grade $\times 2$ nd grade, ${ }^{\mathrm{b}} 1$ st grade $\times 3$ rd grade, ${ }^{\mathrm{c}} 2$ nd grade $\times 3$ rd grade

In addition, the levels of ROM and BAP decreased with advancing grade.

\section{Gender differences}

In male students, the total cholesterol level decreased through the school year, and the level in the first-grade students was higher than that in students from other grades. $\mathrm{RBC}$, hemoglobin, and hematocrit measures increased with progressing grade. In addition, significant differences in triglyceride, HDL-cholesterol, WBC, and platelet levels were also observed among the grades. With respect to ROM and BAP, these levels in males were negatively correlated with grade (Table 3 ).

In females, AST, RBC, and hemoglobin levels decreased with increasing grade, with the value for first-grade students higher than that for the other grades (Table 4). Significant differences were observed in the value of triglycerides among the grades. The level of BAP was higher in the firstgrade students than in students in the other grades.

The level of oxidation and reduction was compared by grade and gender. As shown in Fig. 1, in the third grade, the ROM level in males was significantly lower than that in females $(P<0.01)$, but there were no differences in the other grades. In contrast, the level of BAP in males was negatively correlated with their grade; the values in 1st and 2nd grade male students were significantly higher than those in female students $(P<0.001)$, and the values in 3rd grade male students were also significantly higher $(P<0.01)$.

\section{Discussion}

In the present study, the level of ROM and BAP in serum of healthy Japanese early teenagers was analyzed to determine the current state of oxidative stress during puberty. The present results showed that the levels of ROM and BAP in all subjects were negatively correlated with grade to some extent (Table 2). This tendency was particularly clear in males (Table 3 ). Some previous reports have shown that the level of ROM tends to be independent of gender and age [20], with a very low concentration present in newborns [21] and a higher concentration observed in pregnant women [22, 23]. Although our results, which showed no gender difference in the level of ROM overall, confirmed those reports, a significant difference was observed in the third grade between genders 

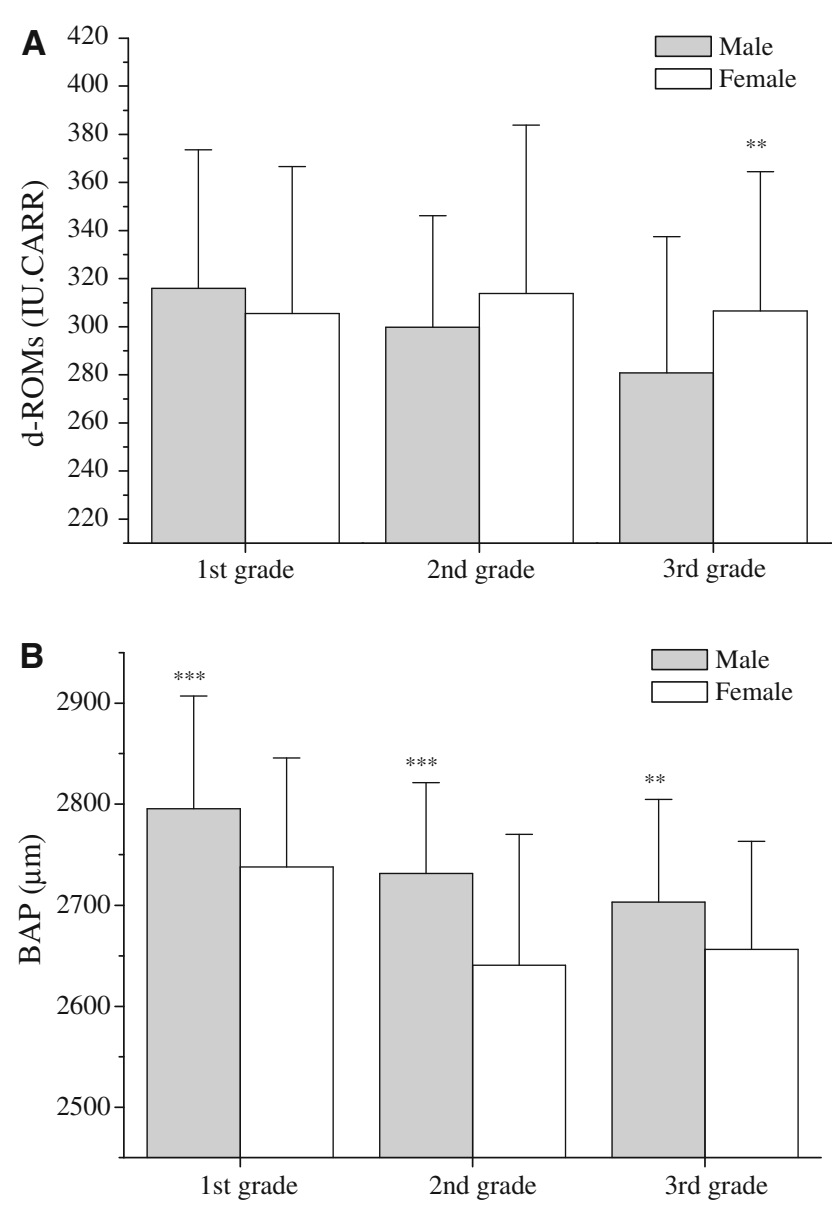

Fig. 1 Comparison of serum d-ROMs levels [the reactive oxygen metabolite (ROM) test] and biological antioxidant potential (BAP) levels in males and females. a There were significant differences in serum d-ROM levels by gender in the third grade $(P<0.01)$. In males, ROM levels were higher in the first grade than in the other grades. b Serum BAP levels in 1st and 2 nd grade were significantly higher in male students than in female students $(P<0.001)$; these levels were also significantly higher in male students from 3rd grade $(P<0.01)$. Male and female BAP levels were higher in the first grade than in the other grades

and among the grades in males. In addition, the value for males in the first grade was almost the same as in adults. Further studies are clearly required to investigate the mechanisms or factor(s) leading to these differences, including whether or not they are related to age and gender.

Factors that increase oxidative stress are known to include bronchial asthma in young children as well as hypertension, diabetes, dyslipidemia, and environmental factors in adults. Since the subjects of this study are healthy junior high school students and their residential environment is a rural area without air pollution and street noise, it cannot reasonably be assumed that any environmental factors caused stress. Therefore, since environmental factors are not likely to be the cause, some physiological factors, such as total cholesterol or RBC- and hemoglobinrelated molecules, may be involved in the stress response. First-grade students entering junior high school from elementary school generally suffer various stresses. Phenomena such as "schoolphobia" and a sharp increase in bullying are called the "Chu-ichi gap" in Japan (Chu-ichi means the first grade in junior high school) [24], and they often contribute to stress. The present study was performed from April to May, just after the start of school; therefore, there is a possibility that the first-grade students had difficulty adjusting to their surroundings and felt stress. However, because the antioxidant capacity (BAP level) in male students was negatively correlated with grade in this study (Table 3; Fig. 1), it was difficult to conclude that the reason was temporary stress due to participants' maladjustment to school. Because the mechanism of ROM and BAP in childhood is unknown, more precise approaches will be required.

The involvement of serum lipids, including LDLs and triglycerides, with various oxidative stresses has been suggested [25, 26]. In infantile obesity, increased malondialdehyde-LDL, which is an oxidized LDL, has been identified, indicating that young individuals may suffer oxidative stress from childhood [27]. The average body size of our subjects was larger than that of other students in Japan [28]. However, relationship of LDL and oxidative stress on the child's developmental stage of growth is unknown, and further analysis is required. A study on adult Japanese individuals reported that the level of ROM in women was higher than in men but concluded that there was no statistically significant difference between the genders [29]. In this study, only the ROM levels showed significant difference between the genders in 3rd grade students, with higher values in female students than in male students (Fig. 1). Furthermore, the ages of the subjects in the present study overlapped the period of development of secondary sex characteristics such as menarche and sperm production, strongly suggesting the involvement of sex hormones in the differences by grade and gender. Together, these results may be related to the effects of obesity, blood lipids, or sex hormones. Additional studies are underway to further investigate the relationship between blood lipids, oxidative stress, and hormones during puberty.

In conclusion, the present study reports the status of oxidative stress during puberty in junior high school students in a rural area. A significant data set was compiled that documented the relationship between oxidative stress and various factors measured during growth and development stages. However, this study is a cross-sectional study, and the data set was obtained in a specific region in one period. Currently, we are investigating more precise approaches to elucidate the role of oxidative stress during these development stages. 
Acknowledgments This study was supported, in part, by the Health and Welfare Section of Nanbu Town, teachers at the junior high school of Nanbu, and the National Health Insurance Nagawa Hospital, Japan. This work was partly supported by a Grant-in-Aid for Scientific Research (C) of the Japan Society for the Promotion of Science (no. 21592845, T.K.).

Conflict of interest The authors declare that they have no conflicts of interest.

\section{References}

1. Whitaker RC, Wright JA, Pepe MS, Seidel KD, Dietz WH. Predicting obesity in young adulthood from childhood and parental obesity. N Engl J Med. 1997;337:869-73.

2. Griendling KK, FitzGerald GA. Oxidative stress and cardiovascular injury: part II: animal and human studies. Circulation. 2003;108:2034-40.

3. Lacy F, O'Connor DT, Schmid-Schönbein GW. Plasma hydrogen peroxide production in hypertensives and normotensive subjects at genetic risk of hypertension. J Hypertens. 1998;16:291-303.

4. Liu L, Ikeda K, Yamori Y. Changes in stroke mortality rates for 1950 to 1997: a great slowdown of decline trend in Japan. Stroke. 2001;32:1745-9.

5. Doi Y, Ninomiya T, Hata J, Fukuhara M, Yonemoto K, Iwase M, et al. Impact of glucose tolerance status on development of ischemic stroke and coronary heart disease in a general Japanese population: the Hisayama Study. Stroke. 2009;41:203-9.

6. Osawa H, Doi Y, Makino $H$, Ninomiya $T$, Yonemoto $K$, Kawamura R, et al. Diabetes and hypertension markedly increased the risk of ischemic stroke associated with high serum resistin concentration in a general Japanese population: the Hisayama Study. Cardiovasc Diabetol. 2009;8:1-8.

7. Belch JJ, Bridges AB, Scott N, Chopra M. Oxygen free radicals and congestive heart failure. Br Heart J. 1991;65:245-8.

8. Mallat Z, Philip I, Lebret M, Chatel D, Maclouf J, Tedgui A. Elevated levels of 8-iso-prostaglandin F2 $\alpha$ in pericardial fluid of patients with heart failure. Circulation. 1998;97:1536-9.

9. Yamanaka G, Ishii C, Kawashima H, Oana S, Miyajima T, Hoshika A. Cerebrospinal fluid diacron-reactive oxygen metabolite levels in pediatric patients with central nervous system diseases. Pediatr Neurol. 2008;39:80-4.

10. Nishikawa T, Okamoto Y, Kodama Y, Tanabe T, Shinkoda Y, Kawano Y. Serum derivative of reactive oxygen metabolites (d-ROMs) in pediatric hemato-oncological patients with neutropenic fever. Pediatr Blood Cancer. 2010;55:291-4.

11. Vaziri ND, Wang XQ, Oveisi F, Rad B. Induction of oxidative stress by glutathione depletion causes severe hypertension in normal rats. Hypertension. 2000;36:142-6.

12. Vaziri ND. Roles of oxidative stress and antioxidant therapy in chronic kidney disease and hypertension. Curr Opin Nephrol Hypertens. 2004;13:93-9.

13. Epton MJ, Dawson RD, Brooks WM, Kingham S, Aberkane T, Cavanagh JA, et al. The effect of ambient air pollution on respiratory health of school children: a panel study. Environ Health. 2008;7:1-11.

14. Noakes PS, Thomas R, Lane C, Mori TA, Barden AE, Devadason $\mathrm{SG}$, et al. Association of maternal smoking with increased infant oxidative stress at 3 months of age. Thorax. 2007;62:714-7.

15. Alberti A, Bolognini L, Macciantelli D, Caratelli M. The radical cation of $N, N$-diethyl-para-phenylenediamine: a possible indicator of oxidative stress in biological samples. Res Chem Intermed. 2000;26:253-67.

16. Iris F, Benzie F, Strain JJ. The ferric reducing ability of plasma (FRAP) as a measure of "antioxidant power": the FRAP assay. Anal Biochem. 1996;239:70-6.

17. The population and the number of households. http://www. town.aomori-nanbu.lg.jp/. Accessed 30 Nov 2011.

18. The investigation of migration statistics in Aomori prefecture. http://www.pref.aomori.lg.jp. Accessed 30 July 2011.

19. Cornelli U, Cornelli M, Terranova R. Free-radical and vascular diseases. Int Union Angiol Bull. 1999;15:7-10.

20. Belcaro G, Carratelli M, Cesarone MR, Cornelli U, Incandela L, Nicolaides A. Oxygen free radicals: a method, a product, an application (abstract). In: Proceedings SFRR Europe Summer Meeting, 1997, pp 183-184.

21. Buonocore G, Perrone S, Longini M, Vezzosi P, Marzocchi B, Paffetti $\mathrm{P}$, et al. Oxidative stress in preterm neonates at birth and on the seventh day of life. Pediatr Res. 2002;52:46-9.

22. Ippolito S, Ambroso G, Mani AR, Novembrino C, Lonati S, Ponticelli $\mathrm{C}$, et al. Oxidative and nitrative status in preeclampsia and normal pregnancy (abstract). Clin Chem Lab Med. 2003; 41(Supplement):301.

23. Wisdom SJ, Wilson R, McKillop JH, Walker JJ. Antioxidant systems in normal pregnancy and in pregnancy-induced hypertension. Am J Obstet Gynecol. 1991;165(6 Pt 1):1701-4.

24. Takahashi M, Koide H, Kitabayashi S, Fukushima S, Sakitani M, Fukushima M, et al. Investigation of the "chuichi gap" (transition to junior high school) with regard to non-attendance at school from the perspective of community psychology. Jpn Women's Univ J Grad Sch Integr Arts Soc Sci. 2010;16:189-204 (Article in Japanese).

25. Yamaoka-Tojo M, Tojo T, Kosugi R, Hatakeyama Y, Yoshida Y, Machida Y, Aoyama N, Masuda T, Izumi T. Effects of ezetimibe add-on therapy for high-risk patients with dyslipidemia. Lipids Health Dis. 2009;8:1-8.

26. Sugiura M, Oikawa T, Hirano K, Maeda $H$, Yoshimura $H$, Sugiyama M, et al. A simple colorimetric method for determination of serum triglycerides with lipoprotein lipase and glycerol dehydrogenase. Clinica Chim Acta. 1977;81:125-30.

27. Kameda K, Kikuchi T, Yamazaki H, Hiura M, Uchiyama M. The relationship of serum levels of malondialdehyde-modified low density lipoprotein to serum lipid and anthropometric measurements in school children. Acta Medica et Biologica. 2003;51: $67-73$.

28. The statistical survey in school health. http://www.mext.go.jp/. Accessed 30 July 2011.

29. Sakane N, Fujiwara S, Sano Y, Domichi M, Tsuzaki K, Matsuoka $\mathrm{Y}$, et al. Oxidative stress, inflammation, and atherosclerotic changes in retinal arteries in the Japanese population: results from the Mima Study. Endocr J. 2008;55:485-8. 